\title{
Outcome predictors for treatment success with 5\% lidocaine medicated plaster in low back pain with neuropathic components and neuropathic pain after surgical and nonsurgical trauma
}

\author{
This article was published in the following Dove Press journal: \\ Journal of Pain Research \\ 10 January 2011 \\ Number of times this article has been viewed
}

\author{
Andrew Nicolaou' \\ Bruce Nicholson ${ }^{2}$ \\ Guy Hans ${ }^{3}$ \\ Louis Brasseur ${ }^{4}$ \\ 'St Georges Hospital, London, UK; \\ ${ }^{2}$ Allentown, Pennsylvania, USA; \\ ${ }^{3}$ Antwerp University Hospital, \\ Edegem, Belgium; ${ }^{4}$ Institut Curie, \\ Saint Cloud, France
}

Correspondence: Guy Hans Multidisciplinary Pain Center, Antwerp University Hospital, Wilrijkstraat I0, 2650

Edegem, Belgium

Tel +3238214945

$\mathrm{Fax}+3238214586$

Email guy.hans@uza.be

\begin{abstract}
Five percent lidocaine medicated plaster has been proven efficacious for the symptomatic relief of neuropathic pain in diverse pain conditions which might be attributed to a common localized symptomatology in these indications, possibly with common predictors of treatment success. To discuss potential symptoms and other factors predicting response to treatment with lidocaine plaster for the indications of low back pain with neuropathic components and neuropathic pain after surgical and nonsurgical trauma, 44 pain specialists from 17 countries attended a two-day conference meeting in December 2009. Discussions were based on the retrospective analysis of case reports (sent in by participants in the four weeks prior to the meeting) and the practical experience of the participants. The results indicate some predictors for success with 5\% lidocaine medicated plaster for the two indications. Localized pain, hyperalgesia and/or allodynia, and other positive sensory symptoms, such as dysesthesia, were considered positive predictors, whereas widespread pain and negative sensory symptoms were regarded as negative predictors. Paresthesia, diagnosis, and site of pain were considered to be of no predictive value. Common symptomatology with other neurologic pathologies suggests that treatment of localized neuropathic pain symptoms with the plaster can be considered across different neuropathic pain indications.
\end{abstract}

Keywords: lidocaine plaster, low back pain, surgical and nonsurgical trauma pain, neuropathic pain, case report

\section{Background}

Five percent lidocaine medicated plaster (Versatis ${ }^{\circledR}$; Grünenthal GmbH, Aachen, Germany) is a topical analgesic which is recommended as first-line therapy for the treatment of localized, peripheral, neuropathic pain. ${ }^{1}$ Its mechanism of action is not fully known, but it is assumed to block sodium channels associated with peripheral nerve endings, thereby reducing ectopic nociceptive pain signal transmission. ${ }^{2}$ The compound has been proven effective and well tolerated in the treatment of neuropathic pain in patients with postherpetic neuralgia ${ }^{3-7}$ and diabetic polyneuropathy. ${ }^{3,4,8}$ Although 5\% lidocaine medicated plaster is currently only licensed for the symptomatic relief of neuropathic pain associated with previous herpes zoster infection (postherpetic neuralgia), it has been successfully used in patients with other neuropathic pain states, such as painful idiopathic distal sensory polyneuropathies, ${ }^{9}$ entrapment neuropathies, ${ }^{10}$ and postoperative/post-traumatic neuropathic chronic cutaneous pain (PNCCP). ${ }^{11,12}$ 
Lidocaine plaster also showed promise in the treatment of chronic low back pain. In two large uncontrolled, open-label studies including patients with moderate-to-severe low back pain, treatment with lidocaine plaster for six weeks significantly reduced the intensity of pain and pain interference with quality of life..$^{13,14}$ The addition of the lidocaine plaster to the analgesic regimen in chronic low back pain was beneficial in a case series of four patients. ${ }^{15}$

Low back pain and PNCCP frequently have complex underlying pathologies. The origin of chronic low back pain is controversially discussed. Amongst other conditions, such as inflammatory back pain, ${ }^{16}$ it is often attributed to degenerative changes in the spine which produce a syndrome of varying combinations of axial and limb pain. ${ }^{17}$ The affected spinal structures may include muscle, nerve, vertebrae, thoracolumbar fascia, ligaments, facet joints, sacroiliac joints, and discs. Spinal degeneration proceeds from stability to instability and back to stability. ${ }^{18}$ Instability is caused by disc dysfunction, tearing, or herniation and restabilization by bony overgrowth of the vertebral end plates and hypertrophy of the facets to compensate for the altered biomechanical loading. ${ }^{18,19}$ Peak incidences of lumbar and radicular pain are reached during the "instability phase". 18,20 Compensatory bone growth results in progressive central canal and foraminal stenosis, leading to neural compression and vascular symptoms. ${ }^{20}$ Both nociceptive and neuropathic pain-generating mechanisms are thought to be involved in low back pain. ${ }^{21}$ For instance, radicular pain is most commonly caused by disc herniation, but the inflammation of the affected nerve seems to be the critical pathophysiologic process. ${ }^{22}$ As in other neuropathic pain conditions, peripheral and central mechanisms are involved in the pathogenesis of (chronic) low back pain. ${ }^{21}$ The present manuscript focuses on low back pain cases considered by their treating physicians to have a definite neuropathic component.

Chronic post-traumatic pain persisting in the location of surgical intervention beyond the usual course of natural healing is common, and has been reported after different types of surgery, eg, amputation, mastectomy, cardiac surgery, hernia repair, and thoracotomy. ${ }^{23}$ It is often due to partial or complete nerve lesions and subsequent development of a focal peripheral neuropathy. ${ }^{11}$ Allodynia or hyperalgesia are frequently observed sensory phenomena if part of the nervous structure is retained (partial lesion) and "overreacts" by, eg, upregulating sodium channels. ${ }^{24}$

The effectiveness of lidocaine plaster in such diverse neuropathic pain conditions might be attributed to a common localized symptomatology in these patients, possibly with common predictors of treatment success. In view of the fact that generally satisfactory pain relief is experienced by $\leq 50 \%$ of patients in randomized clinical trials assessing efficacious neuropathic pain medications (with frequent side effects), ${ }^{25}$ outcome predictors for a given treatment may prove useful in order to save patients in pain from a potentially frustrating "trial and error" period and to find a successful treatment faster, and also be useful from a cost-effectiveness point of view. Two previous conference meetings of pain specialists in Athens, Greece (2007) and Berlin, Germany (2008) had focused on potential outcome predictors for the indications of diabetic polyneuropathy, complex regional pain syndrome, low back pain with neuropathic components (nLBP), and PNCCP. The results of these two meetings have not been published. At those meetings, localized hyperalgesia, allodynia, and a combination of positive and negative symptoms were seen as positive predictors for treatment success with lidocaine plaster in PNCCP, whereas deep pain, numbness, and cold allodynia were discussed as potential negative predictors in such conditions. For low back pain, the specialists summarized their experiences of successful treatment with lidocaine plaster as follows: "For localized myofascial pain with tenderness to touch, with or without positive signs like allodynia and hyperalgesia, excluding radiating and radicular pain and with a neuropathic component". It was, however, generally agreed that further discussions and a definition of predictors for the two indications nLBP and PNCCP on the basis of case reports was warranted. For this purpose, case reports were collected and analyzed at an additional two-day meeting in Vienna, Austria in December 2009. The main results of this meeting are presented in this paper.

\section{Meeting details}

Pain practitioners experienced in the treatment of nLBP or PNCCP with 5\% lidocaine medicated plaster were invited to a two-day meeting facilitated by Grünenthal $\mathrm{GmbH}$ to discuss potential symptoms and other baseline factors predicting response to treatment with lidocaine plaster. The discussions were based on the retrospective analysis of case reports and the practical experience of the participants. Forty-four pain specialists from 17 countries participated in this meeting. Two discussion groups for each clinical indication were formed, each moderated by one of the four authors of this paper.

Four weeks prior to the meeting, all participants were asked to contribute case reports for nLBP and/or PNCCP. 
The time frame was felt appropriate for the retrospective collection of data but was insufficient for starting treatment de novo in view of the request (which was not permitted). Practitioners provided information about their cases using a standardized form documenting the following:

- Demographic data

- Primary diagnosis (pain indication/cause of pain)

- Other relevant diagnoses

- Localization of pain symptoms

- Duration and intensity of pain prior to initiation of treatment with lidocaine plaster

- Physical examination and diagnostic tests

- Presence of clinical symptoms of pain (hyperalgesia, severity of allodynia, stabbing pain, burning pain, shooting pain, other symptoms)

- Prior and concomitant medication

- Start of therapy with lidocaine plaster

- Application frequency, number of plasters and duration of treatment

- Clinical Global Impression of Change (CGIC) score during treatment with lidocaine plaster (from 1 "very much improved" to 6 "very much worse")

- Occurrence of adverse events

- Conclusions of the practitioner

The presence of hyperalgesia (increased pain sensitivity in response to nociceptive stimuli) and allodynia (pain response to nonnociceptive stimuli) was confirmed by the treating physician using diagnostic tools of his/her choice. Practitioners rated the severity of allodynia on a scale from $0=$ no pain or discomfort to touch, $1=$ uncomfortable, but tolerable to touch, 2 = painful, to 3 = extremely painful, patient cannot stand touching.

Twenty-four pain practitioners from Austria $(n=1)$, Belgium (4), Croatia (1), France (1), Germany (2), Poland (3), Portugal (3), Russia (1), Slovenia (1), Spain (2), United Kingdom (4), and Venezuela (1) submitted a total of 89 case reports. All reports were tabulated according to indication and displayed during the discussion sessions. The original report forms were also available for perusal at each session. In 17 cases, both etiologies were present; these cases were discussed for both indications. All cases were reviewed jointly by the group participants and provided a basis for the first discussions in the four groups. From this starting point, the discussions moved on to an exchange of experience between the specialists regarding outcome predictors. Final conclusions were drawn collectively after the group discussions.

\section{Chronic low back pain with neuropathic components}

The two groups reviewed 41 cases of chronic low back pain with neuropathic components. Table 1 summarizes these cases across different etiologies and lists them sorted by degree of improvement (CGIC score). The 17 cases where both etiologies were present (nLBP and PNCCP) are tabulated in Table 2, but baseline data were included in calculations for both nLBP and PNCCP.

Patients were mainly Caucasian (88\%), with a mean age of $55.9 \pm 15.7$ years and a slightly higher proportion of females $(58.5 \%)$. Mean duration of pain was $3.9 \pm 5.2$ years. The majority of patients had received multiple pain medications during the course of their disease. Lidocaine medicated plaster was administered as monotherapy in nine patients $(22.0 \%)$ and in combination with other pain medication in 32 patients $(78.0 \%)$.

In $31(76 \%)$ of the reports, patients were judged as much or very much improved following treatment with 5\% lidocaine medicated plaster as determined by the CGIC. Minimal improvement was reported for nine patients and "no change" was documented in one case. In the group receiving monotherapy or continuing their previous medication in combination with the plaster, ie, the subset of patients in which the treatment outcome was most likely related to the use of lidocaine plaster, nine patients $(69 \%)$ experienced much or very much improvement and four (31\%) showed minimal improvement.

Hyperalgesia was more prevalent at baseline in patients showing much or very much improvement than in patients with minimal or no improvement ( $81 \%$ versus $60 \%$ ). The presence of allodynia was documented for the majority of all patients $(71 \%)$ with no difference when stratified by improvement. Severity of allodynia ("painful" or "extremely painful") was comparable in much or very much improved patients $(45 \%)$ to minimally or not improved patients (40\%). A total of $36 \%$ of the patients with much or very much improvement had a history of both hyperalgesia and painful allodynia compared with $20 \%$ of the patients with no or minimal improvement. Although these case reports do not show a clear association between the presence of allodynia and a positive treatment outcome, it was concluded based on the experience of the practitioners that the presence of hyperalgesia and/or allodynia may favor a positive treatment outcome using 5\% lidocaine medicated plaster, in particular if painful allodynia is the predominant pain complaint. 
Table I Case reports for neuropathic low back pain

\begin{tabular}{|c|c|c|c|c|c|}
\hline Gender & Age & $\begin{array}{l}\text { Primary diagnosis (pain } \\
\text { indication/cause of pain) }\end{array}$ & $\begin{array}{l}\text { Localization of } \\
\text { pain symptoms }\end{array}$ & $\begin{array}{l}\text { Duration of pain } \\
\text { in years }\end{array}$ & Hyperalgesia \\
\hline $\mathrm{F}$ & 50 & $\begin{array}{l}\text { Neuropathic pain, viral } \\
\text { radiculitis }\end{array}$ & Periumbilical pain, allodynia & 2.0 & $x$ \\
\hline $\mathrm{F}$ & 85 & Lumbar pain & Lumbar & 10.0 & \\
\hline $\mathrm{F}$ & 29 & Discopathy & Low back pain & 0.06 & $x$ \\
\hline $\mathrm{F}$ & 76 & $\begin{array}{l}\text { Low back pain }>\text { facet } \\
\text { arthrosis }\end{array}$ & Low back & $\geq 5.0$ & $\mathrm{X}$ \\
\hline $\mathrm{F}$ & 56 & $\begin{array}{l}\text { Low back pain }>\text { facet } \\
\text { arthrosis }\end{array}$ & Low back & 0.5 & $x$ \\
\hline $\mathrm{F}$ & 58 & Lumbosacral syndrome & $\begin{array}{l}\text { Low back pain, irradiating } \\
\text { to both thighs; knees }\end{array}$ & 3.0 & $x$ \\
\hline M & 69 & Lumbar-sciatic pain & $\begin{array}{l}\text { Low back pain irradiating } \\
\text { into lateral and posterior } \\
\text { part of the right leg }\end{array}$ & 0.17 & $x$ \\
\hline M & 59 & Lumbar pain/radiculopathy & Lumbar & 3.0 & $x$ \\
\hline $\mathrm{F}$ & 43 & Lumbar pain/radiculopathy & Lumbosacral & 2.0 & $x$ \\
\hline $\mathrm{F}$ & $4 I$ & Sciatica & Left leg & 0.5 & $x$ \\
\hline$M$ & 50 & Low back pain + sciatic pain & Low back and left leg $\sim$ SI & 5.0 & $x$ \\
\hline$M$ & 45 & Neuropathic pain & Cervical spine, lumbar spine & 18.0 & $x$ \\
\hline$M$ & 38 & Low back pain $>$ discopathy & Low back and left hip & 0.17 & $x$ \\
\hline $\mathrm{F}$ & 81 & Arthrosis zygapophyseal joint & Low back & 5.0 & \\
\hline $\mathrm{F}$ & 44 & Arthrosis zygapophyseal joint & Low back & $\geq 5.0$ & \\
\hline $\mathrm{F}$ & 55 & $\begin{array}{l}\text { Arthrosis zygapophyseal joint }+ \\
\text { sacroiliac joint }\end{array}$ & Low back pain & 0.83 & \\
\hline M & 55 & low back pain-spondylolisthesis & Low back pain & 0.33 & $x$ \\
\hline M & 86 & low back pain & Low back pain & 0.17 & $\mathrm{x}$ \\
\hline NA & 54 & Degenerative disc disease & Low back pain & 1,33 & $x$ \\
\hline $\mathrm{F}$ & 50 & Lumbar pain & Right buttock, scar & 0.5 & $x$ \\
\hline$M$ & 80 & Low back pain & Low back & 20.0 & $x$ \\
\hline $\mathrm{F}$ & 71 & Sciatic pain bilateral & SI bilateral & 10.0 & $x$ \\
\hline M & 54 & Low back pain & Low back & 1.0 & $x$ \\
\hline $\mathrm{F}$ & 62 & Lumbosacral syndrome & $\begin{array}{l}\text { Low back pain irradiating } \\
\text { into both legs knees } \\
\text { hands and feet }\end{array}$ & 10.0 & $x$ \\
\hline $\mathrm{F}$ & 55 & Arthrosis zygapophyseal joint & Low back & $\geq 5.0$ & \\
\hline $\mathrm{F}$ & 80 & Arthrosis zygapophyseal joint & Low back left + right & $\geq 5.0$ & \\
\hline$M$ & 68 & Lumbar pain & Lumbar & 7.0 & $x$ \\
\hline
\end{tabular}

The presented case reports showed that patients with minimal improvement had a considerably longer duration of pain (mean 6.7 years) compared with very much (mean 4.1 years) and much improved (mean 3.5 years) patients. In the opinion of the majority of the physicians, patients with a long history of pain are less likely to benefit from lidocaine plaster and best results are obtained if the treatment is initiated early. However, it was conceded that this is applicable to pain medication in general.

Another factor thought to be a positive predictor for treatment with lidocaine plaster is the ability of patients to differentiate between back pain and nonback pain components, whereas the inability to distinguish between pain locations and predominant radicular pain was regarded as a negative predictor. 
Table I (Continued)

\begin{tabular}{|c|c|c|c|c|c|c|c|}
\hline $\begin{array}{l}\text { Allodynia/allodynia } \\
\text { severity rating }\end{array}$ & $\begin{array}{l}\text { Stabbing } \\
\text { pain }\end{array}$ & $\begin{array}{l}\text { Burning } \\
\text { pain }\end{array}$ & $\begin{array}{l}\text { Shooting } \\
\text { pain }\end{array}$ & Monotherapy & $\begin{array}{l}\text { Plasters } \\
\text { per day }\end{array}$ & $\begin{array}{l}\text { Duration of plaster } \\
\text { treatment (months) }\end{array}$ & $\begin{array}{l}\text { CGIC } \\
\text { score }\end{array}$ \\
\hline 2 & $x$ & $x$ & $x$ & $Y$ & 1 & $\begin{array}{l}17 \\
\text { ongoing }\end{array}$ & 1 \\
\hline $2-3$ & & $x$ & & $\mathrm{~N}$ & I & 3 & 1 \\
\hline 0 & $x$ & & & $\mathrm{Y}$ & I & 1.5 & 1 \\
\hline I & $x$ & & & $Y$ & I & 10 & 1 \\
\hline I & & & $\mathrm{X}$ & $Y$ & 1 & 1.5 & 1 \\
\hline I & & $x$ & & $\mathrm{~N}$ & $\begin{array}{l}\text { I } \\
3 \text { days; then } \\
\text { every } 3 r d \text { day }\end{array}$ & 0.5 & 2 \\
\hline 2 & $x$ & $x$ & & $\mathrm{~N}$ & $\begin{array}{l}\text { I } \\
3 \text { days; then } \\
\text { every } 3 r d \text { day }\end{array}$ & 0.5 & 2 \\
\hline 2 & & $\mathrm{X}$ & & $\mathrm{N}$ & 2 & $\begin{array}{l}\text { I } \\
\text { ongoing }\end{array}$ & 2 \\
\hline 2 & & $x$ & & $\mathrm{~N}$ & I & 3 & 2 \\
\hline I & $\mathrm{X}$ & $x$ & $\mathrm{X}$ & $\mathrm{N}$ & I & $\begin{array}{l}3 \\
\text { ongoing }\end{array}$ & 2 \\
\hline I & $x$ & & $x$ & $\mathrm{~N}$ & 1 & I & 2 \\
\hline 2 & $X$ & $x$ & $\mathrm{X}$ & $\mathrm{N}$ & 1 & 3 & 2 \\
\hline 2 & & $x$ & & $\mathrm{~N}$ & I & $\begin{array}{l}5 \\
\text { ongoing }\end{array}$ & 2 \\
\hline 2 & $x$ & $x$ & $x$ & $Y$ & I & 0.75 & 2 \\
\hline 2 & $x$ & $x$ & $x$ & $\mathrm{~N}$ & I & I & 2 \\
\hline 2 & $x$ & $x$ & & $Y$ & I & 1 & 2 \\
\hline NA & & $x$ & $x$ & $\mathrm{~N}$ & $\mathrm{I} / 4$ & 3 & 2 \\
\hline NA & & & $x$ & $\mathrm{~N}$ & $\begin{array}{l}\text { I/8 } \\
\text { twice a week }\end{array}$ & 1 & 2 \\
\hline NA & & $x$ & $\mathrm{X}$ & $\mathrm{N}$ & $\begin{array}{l}\text { I/4 } \\
\text { twice a week }\end{array}$ & 2 & 2 \\
\hline NA & $\begin{array}{l}\mathrm{X} \text { at right } \\
\text { buttock }\end{array}$ & & & $\mathrm{N}$ & 2 & 10 & 3 \\
\hline 0 & & & $\mathrm{X}$ & $\mathrm{N}$ & I & 0.75 & 3 \\
\hline 0 & $x$ & & $x$ & $\mathrm{~N}$ & 2 & 0.5 & 3 \\
\hline 0 & $x$ & & $x$ & $\mathrm{Y}$ & 1 & I & 3 \\
\hline 2 & $x$ & $x$ & & $\mathrm{~N}$ & $\begin{array}{l}\text { I } \\
3 \text { days; then } \\
\text { every } 3 r d \text { day }\end{array}$ & I & 3 \\
\hline 2 & $x$ & $x$ & & $Y$ & 1 & 0.25 & 3 \\
\hline 0 & $x$ & $x$ & & $\mathrm{~N}$ & 1 & 1.5 & 3 \\
\hline 3 & $x$ & $x$ & $x$ & $\mathrm{~N}$ & 2 & 3 & 4 \\
\hline
\end{tabular}

Notes: Allodynia severity rating: $0=$ no pain or discomfort to touch, I = uncomfortable, but tolerable to touch, $2=$ painful, $3=$ extremely painful, patient cannot stand touching; duration of pain was converted to years, term "many years" was set to $\geq 5$ years in Table I and to 5 years for calculation of means.

Abbreviations: CGIC, Clinical Global Impression of Change $(I=$ very much improved, $2=$ much improved, $3=$ minimally improved, $4=$ no change, $5=$ minimally worse, 6 = very much worse); F, female; $M$, male; NA, not available; $X$, symptom present.

Diagnosis and site of pain were considered to have no predictive value. Also, the description of neuropathic pain quality as given in the case reports (eg, burning, stabbing, shooting) was judged as not reliable enough for the prediction of treatment outcome, although clustering of the case reports by primary diagnosis revealed that, for instance, seven of eight patients presenting with failed back surgery syndrome reported clinical symptoms of burning pain (with and without hyperalgesia and/or allodynia), only one reported stabbing pain, and seven of those patients showed much or very much improvement (minimal improvement in the remaining one patient). Overall, two-thirds of the patients with nLBP $(68.3 \%)$ reported burning pain, but no clear relationship between this symptom and clinical outcome was seen. However, this analysis of the case reports was not in 
Table 2 Case reports for neuropathic low back pain after surgical trauma

\begin{tabular}{|c|c|c|c|c|c|}
\hline Gender & Age & $\begin{array}{l}\text { Primary diagnosis } \\
\text { (pain indication/cause } \\
\text { of pain) }\end{array}$ & $\begin{array}{l}\text { Localization } \\
\text { of pain symptoms }\end{array}$ & $\begin{array}{l}\text { Duration } \\
\text { of pain in years }\end{array}$ & Hyperalgesia \\
\hline $\mathrm{F}$ & 75 & $\begin{array}{l}\text { Failed back surgery syndrome: laminectomy } \\
\text { L4-L5 + decompression and fusion with } \\
\text { supplemental instrumentation - Nov 2008; } \\
\text { 2nd surgery } 24 \text { hours after the Ist one - pain } \\
\text { and right foot dorsiflexion paresis }\end{array}$ & $\begin{array}{l}\text { lumbar back pain and right leg } \\
\text { paresthesias and dysesthesias }\end{array}$ & 0.58 & $\mathrm{X}$ \\
\hline $\mathrm{F}$ & 49 & $\begin{array}{l}\text { Failed back surgery syndrome focal } \\
\text { neuropathic back pain }\end{array}$ & back, around the postoperative scar & 0.33 & $\mathrm{X}$ \\
\hline M & 22 & $\begin{array}{l}\text { Low back pain after lumbar puncture } \\
\text { for spinal anesthesia (for circumcision) })^{\mathrm{a}}\end{array}$ & $\begin{array}{l}\text { axial pain in the point of puncture } \\
\text { and nearby L3-L4 }\end{array}$ & 0.17 & $x$ \\
\hline M & 69 & $\begin{array}{l}\text { TURP Feb } 1990 \text { failed back surgery syndrome - } \\
\text { spine surgery (1992) to perform drainage of } \\
\text { spine epidural empyema in the context of Conn } \\
\text { syndrome (saddle anesthesia, bladder and bowel } \\
\text { dysfunction) }\end{array}$ & lumbar pain, around incision scar & 18.0 & $x$ \\
\hline $\mathrm{F}$ & 52 & Failed back surgery syndrome & back & 5.0 & \\
\hline $\mathrm{F}$ & 67 & $\begin{array}{l}\text { Fracture LI, traffic accident; spine surgery } \\
\text { April 2004; 2006: 2nd spine surgery for material } \\
\text { extraction }\end{array}$ & $\begin{array}{l}\text { low back pain, incidental, like } \\
\text { stabbing; since second surgery. } \\
\text { without irradiation }\end{array}$ & 3.0 & $x$ \\
\hline M & 63 & Lumbar pain/postsurgical, lumbar pain L4-L5 & $\begin{array}{l}\text { lumbar (scar) + neuropathic pain } \\
\text { right lower limb }\end{array}$ & 0.33 & $x$ \\
\hline M & 35 & $\begin{array}{l}\text { Postlaminectomy L5-SI and surgery for lumbar } \\
\text { herniated disc L4-L5 }\end{array}$ & left foot & 0.08 & $\mathrm{x}$ \\
\hline $\mathrm{F}$ & 35 & $\begin{array}{l}\text { Neck pain post failed surgery, nociceptive } \\
\text { and neuropathic pain }\end{array}$ & $\begin{array}{l}\text { cervicobrachial } \\
\text { left area }\end{array}$ & 2.0 & $x$ \\
\hline $\mathrm{F}$ & 44 & Failed back surgery syndrome & low back & 1.0 & \\
\hline M & 49 & Failed back surgery & low back & 3.0 & $x$ \\
\hline $\mathrm{F}$ & 36 & Failed back surgery syndrome & low back pain & 2.0 & $\mathrm{x}$ \\
\hline $\mathrm{F}$ & 82 & Failed back surgery syndrome & back and right buttock & 0.5 & $x$ \\
\hline M & 52 & Failed back surgery & lumbar spine & 5.0 & \\
\hline $\mathrm{F}$ & 48 & Failed back surgery syndrome & low back, left leg & 4.0 & \\
\hline M & 39 & Failed back surgery & $\begin{array}{l}\text { back and left part } \\
\text { of low back }\end{array}$ & 3.0 & $\mathrm{x}$ \\
\hline $\mathrm{F}$ & 43 & Painful surgery (NR) & NR & 0.5 & $x$ \\
\hline
\end{tabular}

agreement with the general experience of the participants, who considered burning, stabbing, and shooting pain as predictors of treatment success with 5\% lidocaine medicated plaster.

Treatment with the lidocaine plaster led to much improvement in a 35-year-old male patient presenting with pain in his left foot following laminectomy at L5-S1 and surgery for a herniated disc at L4-L5. The patient initially presented with hyperalgesia, painful allodynia, and burning and stabbing pain with an average intensity of 9 out of 10 on a visual analog scale (VAS). Physical examination and diagnostic tests revealed reduced strength due to pain, pain during walking, and superficial sensitivity, ie, diffuse hypoesthesia in the left inferior limb and reduced patellar reflexes. The patient received three months of add-on treatment with one lidocaine plaster every 12 hours on the lateral side of the affected foot (with concomitant tramadol, 5 to 8 drops orally, corresponding to $12.5-20 \mathrm{mg}$ every eight hours). At the end of the lidocaine plaster treatment, the patient showed much improvement, with occasional pain if a shoe was too tight or if he walked long distances.

Very much improvement in pain following lidocaine plaster monotherapy was reported for a 50-year-old female patient with localized, periumbilical, neuropathic pain (viral radiculitis) with an average intensity of 6 to 8 out of 10 on a VAS scale. The patient presented with hyperalgesia, painful allodynia, stabbing, burning, and shooting pain which had 
Table 2 (Continued)

\begin{tabular}{|c|c|c|c|c|c|c|c|}
\hline $\begin{array}{l}\text { Allodynia/allodynia } \\
\text { severity rating }\end{array}$ & $\begin{array}{l}\text { Stabbing } \\
\text { pain }\end{array}$ & $\begin{array}{l}\text { Burning } \\
\text { pain }\end{array}$ & $\begin{array}{l}\text { Shooting } \\
\text { pain }\end{array}$ & Monotherapy & Plasters per day & $\begin{array}{l}\text { Duration of plaster } \\
\text { treatment (months) }\end{array}$ & CGIC score \\
\hline 2 & & $x$ & & $\mathrm{~N}$ & 1 & $\begin{array}{l}6 \\
\text { ongoing }\end{array}$ & $\begin{array}{l}\text { I - on the } \\
\text { back }\end{array}$ \\
\hline I & & $\mathrm{x}$ & & $Y$ & 1 & 1 & 1 \\
\hline I & $x$ & & & $\mathrm{~N}$ & $1 / 4$ & 2 & I \\
\hline $2-3$ & $\mathrm{X}$ & & $\mathrm{X}$ & $\mathrm{N}$ & 1 & $\begin{array}{l}8 \\
\text { ongoing }\end{array}$ & 1 \\
\hline I & & $\mathrm{X}$ & & $\mathrm{N}$ & 1 & $\begin{array}{l}5 \\
\text { ongoing }\end{array}$ & 2 \\
\hline 0 & $\mathrm{X}$ & & & $\mathrm{N}$ & I & $\begin{array}{l}6 \\
\text { ongoing }\end{array}$ & 2 \\
\hline$x$ & $\mathrm{x}$ & & & $\mathrm{N}$ & $1 \mid / 2$ & 10 & 2 \\
\hline 2 & & $\mathrm{x}$ & $x$ & $\mathrm{~N}$ & 1 & 3 & 2 \\
\hline 2 & & & $x$ & $\mathrm{~N}$ & 1 & 3 & 2 \\
\hline I & & $x$ & & $\mathrm{~N}$ & 1 & 2 & 2 \\
\hline 0 & & $x$ & & $\mathrm{~N}$ & 1 & 3 & 2 \\
\hline 0 & & $x$ & & $\mathrm{~N}$ & $1 / 4$ & 3 & 2 \\
\hline 0 & & $x$ & $x$ & $\mathrm{~N}$ & 1 & 1.5 & 3 \\
\hline 1 & $x$ & $x$ & & $\mathrm{~N}$ & $11 / 2$ & 1.5 & 3 \\
\hline 2 & & $x$ & $x$ & $\mathrm{~N}$ & 2 & 0.75 & 3 \\
\hline 0 & & $\mathrm{x}$ & $x$ & $\mathrm{~N}$ & 1 & 0.5 & $5-6$ \\
\hline 3 & & & & $\mathrm{~N}$ & 1 & $\begin{array}{l}7 \\
\text { ongoing }\end{array}$ & NA \\
\hline
\end{tabular}

Notes: aParesthesias and dysesthesias. Allodynia severity rating: $0=$ no pain or discomfort to touch, $I=$ uncomfortable, but tolerable to touch, $2=$ painful, $3=$ extremely painful, patient cannot stand touching; duration of pain was converted to years, term "many years" was set to $\geq 5$ years in the table and to 5 years for calculation of means.

Abbreviations: CGIC, Clinical Global Impression of Change ( 1 = very much improved, $2=$ much improved, $3=$ minimally improved, $4=$ no change, $5=$ minimally worse, 6 = very much worse); F, female; M, male; NA, not available; NR, not readable; TURP, transurethral resection of prostate; X, symptom present.

lasted for two years prior to initiation of lidocaine plaster treatment.

Unsatisfactory treatment with lidocaine plaster was reported for a 62-year-old polymorbid male patient (diabetes, polyneuropathy, hypothyreosis, high blood pressure, psoriatic arthritis) with a diagnosis of lumbosacral syndrome and low back pain radiating into both legs, knees, hands, and feet (10 out of 10 on a VAS scale). He had been in pain for 10 years, with hyperalgesia, painful allodynia, and stabbing and burning pain symptoms. He improved minimally when lidocaine therapy was added to his pre-existing medications (nonsteroidal anti-inflammatory drugs and a combination of a weak opioid and paracetamol).
While most clinical experience of the lidocaine plaster is with neuropathic pain, one of the nLBP groups felt that patients with structural abnormalities of the spinal cord, even though the cause has usually been characterized as nociceptive, may respond to topical treatment with lidocaine and that this should be explored in the future.

\section{Chronic neuropathic pain after surgical and nonsurgical trauma}

Fifty-eight case reports with a diagnosis of PNCCP were submitted $(51.7 \%$ male, mean age $50.1 \pm 15.5$ years, mean duration of pain $2.6 \pm 4.5$ years, Table 3 ). The 17 cases 
Table 3 Case reports for neuropathic pain after surgical and nonsurgical trauma

\begin{tabular}{|c|c|c|c|c|c|}
\hline Gender & Age & $\begin{array}{l}\text { Primary diagnosis } \\
\text { (pain indication/cause of pain) }\end{array}$ & Localization of pain symptoms & $\begin{array}{l}\text { Duration of } \\
\text { pain in years }\end{array}$ & Hyperalgesia \\
\hline $\mathrm{F}$ & 54 & $\begin{array}{l}\text { Longstanding low back pain and } \\
\text { left knee pain post } T K R^{a}\end{array}$ & Left knee & 0.17 & \\
\hline $\mathrm{F}$ & 65 & After knee surgery 7 years ago & Right knee, infrapatellar nerve & 6.0 & $x$ \\
\hline $\mathrm{F}$ & 30 & Tibial fracture and osteosynthesis & anterior aspect of the skin (scar area) & 0.5 & \\
\hline $\mathrm{F}$ & 46 & $\begin{array}{l}\text { Post-traumatic neuropathic pain } \\
\text { (dog attack) }\end{array}$ & $\begin{array}{l}\text { Severe pain in the right lower calf }+ \\
\text { ankle on all weight bearing activities }\end{array}$ & 1.5 & $\mathrm{x}$ \\
\hline M & 55 & $\begin{array}{l}\text { Breast cancer; staging IIA, T2NOM0, } \\
\text { status after right mastectomy ( }(\mathrm{m}) \text {, } \\
\text { postmastectomy (postsurgery) } \\
\text { painful syndrome }\end{array}$ & $\begin{array}{l}\text { severe shooting pain in the right } \\
\text { hand, burning pain upon the light } \\
\text { touch in the region under the } \\
\text { postoperative scar }\end{array}$ & 0.08 & $x$ \\
\hline $\mathrm{F}$ & 18 & Scar neuralgia postfracture & Forearm & 2.0 & $x$ \\
\hline M & 43 & Neuropathic pain ${ }^{\mathrm{b}}$ & left inguinal region & 1.67 & $x$ \\
\hline M & 41 & $\begin{array}{l}\text { Renal malignant tumor surgery, } \\
\text { acute neuropathic pain }\end{array}$ & postoperative wound & 0.02 & $x$ \\
\hline M & 69 & $\begin{array}{l}\text { Persistent postoperative pain } \\
\text { post-thoracotomy }\end{array}$ & right side of chest wall & 0.33 & \\
\hline M & 45 & Inguinal neuralgia posthernia repair & groin & 0.25 & $x$ \\
\hline $\mathrm{F}$ & 31 & Post-traumatic right knee pain & Right anterior knee & 1.33 & $x$ \\
\hline $\mathrm{F}$ & 41 & $\begin{array}{l}\text { Complex regional pain } \\
\text { syndrome II, and wrist NR }\end{array}$ & Back of right hand and medial aspect & 2.5 & $x$ \\
\hline M & 59 & $\begin{array}{l}\text { Neuropathic postsurgical } \\
\text { (TKR) knee pain }\end{array}$ & Right anterior knee & 2.0 & $x$ \\
\hline M & 82 & $\begin{array}{l}\text { Sarcoma of soft tissues of right } \\
\text { gluteus region, staging T2NIMX. } \\
\text { A severe somatic painful syndrome } \\
\text { with neuropathic component. }\end{array}$ & $\begin{array}{l}\text { Severe pain in the right gluteus } \\
\text { region, shooting pain in the right } \\
\text { leg from the hip to the foot, } \\
\text { burning pain at the median surface } \\
\text { of the right hip }\end{array}$ & 0.17 & $x$ \\
\hline $\mathrm{F}$ & 57 & $\begin{array}{l}\text { Thoracic pain after } 2 \text { thoracotomies } \\
\text { (Aug and Sept 2008), pulmonary } \\
\text { empyema (right lung) }{ }^{c}\end{array}$ & $\begin{array}{l}\text { permanent and persistent thoracalgia, } \\
\text { very severe; level T7 and T8, on the } \\
\text { right side; Persistent pain at rectus } \\
\text { supraumbilical muscle }\end{array}$ & 0.58 & $\mathrm{x}$ \\
\hline $\mathrm{F}$ & 42 & $\begin{array}{l}\text { Postoperative pain after breast } \\
\text { reconstruction }\end{array}$ & back & 0.5 & $\mathrm{x}$ \\
\hline $\mathrm{F}$ & 46 & Poststernotomy painful keloid & scar of sternotomy & 3.0 & \\
\hline $\mathrm{F}$ & 80 & Postknee replacement pain & knee (anterior) & 0.5 & \\
\hline $\mathrm{F}$ & 58 & $\begin{array}{l}\text { Reflected ligament fracture, then } \\
\text { acute median nerve compression } \\
\text { requiring surgery; Complex regional } \\
\text { pain syndrome (neuropathic) }\end{array}$ & $\begin{array}{l}\text { Intolerant of shower/light } \\
\text { clothing over upper chest wall }\end{array}$ & 2.0 & $x$ \\
\hline M & 56 & Post-thoracotomy pain & area of the thoracic surgery & 0.25 & \\
\hline M & 64 & Phantom pain & left stump of lower leg & 23.0 & $\mathrm{x}$ \\
\hline M & 42 & $\begin{array}{l}\text { Pain in the chest, status } \\
\text { postoperative neuropathic pain }\end{array}$ & Right costal arch & 2.0 & $\mathrm{x}$ \\
\hline M & 55 & $\begin{array}{l}\text { Neuropathy of the left mental nerve } \\
\text { after excision of tumor of mandible }\end{array}$ & left side of the chin & 1.0 & $x$ \\
\hline M & 24 & Inguinal neuralgia posthernia repair & groin & 0.75 & $x$ \\
\hline M & 48 & Lumbar disc herniation surgery & external aspect of left thigh and leg & 1.0 & \\
\hline M & 38 & $\begin{array}{l}\text { Postsurgical painful scar after } \\
\text { elbow surgery }\end{array}$ & left elbow & 3.0 & \\
\hline M & 64 & $\begin{array}{l}\text { Intercostal painful neuropathy } \\
\text { (post-traumatic) }\end{array}$ & dermatome right side & $>20.0$ & $\mathrm{x}$ \\
\hline M & 65 & Postherniorrhaphy pain & Inguinal/groin area & 1.5 & $\mathrm{x}$ \\
\hline M & 29 & Testicular neuralgia & left testis & 0.25 & \\
\hline
\end{tabular}


Table 3 (Continued)

\begin{tabular}{|c|c|c|c|c|c|c|c|}
\hline $\begin{array}{l}\text { Allodynia/allodynia } \\
\text { severity rating }\end{array}$ & $\begin{array}{l}\text { Stabbing } \\
\text { pain }\end{array}$ & $\begin{array}{l}\text { Burning } \\
\text { pain }\end{array}$ & $\begin{array}{l}\text { Shooting } \\
\text { pain }\end{array}$ & Monotherapy & $\begin{array}{l}\text { Plasters } \\
\text { per day }\end{array}$ & $\begin{array}{l}\text { Duration of plaster } \\
\text { treatment (months) }\end{array}$ & CGIC score \\
\hline 1 & & & & $Y$ & 3 & 4 & 1 \\
\hline $2-3$ & $x$ & $x$ & & $\mathrm{~N}$ & NA & 12 & I \\
\hline 1 & & $x$ & $x$ & $\mathrm{~N}$ & $1 / 2$ & 2 & I \\
\hline 3 & $x$ & $x$ & $x$ & $N$ & I I/2 & 18 & 1 \\
\hline 3 & & $x$ & $x$ & $\mathrm{~N}$ & 3 & $\begin{array}{l}0.5 \\
\text { then occasionally } \\
\text { for } 2 \text { months }\end{array}$ & 1 \\
\hline 2 & & $x$ & & $Y$ & $1 / 2$ & 1 & I \\
\hline 2 & $x$ & $x$ & $x$ & $\mathrm{~N}$ & I & $\begin{array}{l}27 \\
\text { ongoing }\end{array}$ & 1 \\
\hline 3 & $x$ & $x$ & $x$ & $Y$ & I & 0.25 & 1 \\
\hline 2 & & $x$ & $x$ & $\mathrm{~N}$ & $\mathrm{I} / 2$ & 2 & 1 \\
\hline 3 & $x$ & $x$ & & $Y$ & 2 & 6 & I \\
\hline 2 & $x$ & & & $Y$ & 2 & 1.5 & 2 \\
\hline 2 & & & $x$ & $Y$ & $\begin{array}{l}\text { I; } 2-3 \text { days in } \\
\text { the evening }\end{array}$ & 9 & 2 \\
\hline 3 & $x$ & & $x$ & $\mathrm{~N}$ & 2 & 2 & 2 \\
\hline 2 & $x$ & $x$ & $x$ & $\mathrm{~N}$ & 2 & 1 & 2 \\
\hline \multirow[t]{2}{*}{3} & $x$ & $x$ & $x$ & $\mathrm{~N}$ & I & 8 & $2^{g}$ \\
\hline & & & & & & ongoing & $3^{h}$ \\
\hline 2 & & $x$ & & $\mathrm{~N}$ & $\mathrm{I} \mathrm{I} / 2$ & NA & 2 \\
\hline I & & $x$ & & $\mathrm{~N}$ & I & I & 2 \\
\hline 2 & $x$ & $x$ & & $\mathrm{~N}$ & I & 14 & 2 \\
\hline 3 & & $x$ & & $N$ & 2 & 15 & 2 \\
\hline 2 & & $x$ & & $\mathrm{~N}$ & I & 8 & 2 \\
\hline 2 & & & $x$ & $N$ & 1 & $\begin{array}{l}15 \\
\text { ongoing }\end{array}$ & 2 \\
\hline 2 & $x$ & $x$ & $x$ & $\mathrm{~N}$ & 1 & $\begin{array}{l}15 \\
\text { ongoing }\end{array}$ & 2 \\
\hline 2 & $x$ & & & $Y$ & $\mathrm{I} / 4$ & 2 & 2 \\
\hline 0 & $x$ & $x$ & & $Y$ & I & NA & 2 \\
\hline I & & $x$ & $x$ & $\mathrm{~N}$ & $\mathrm{I} / 2$ & 2 & 2 \\
\hline 2 & & & $x$ & $Y$ & $1 / 2$ & 7 & 2 \\
\hline 3 & $x$ & & & $\mathrm{~N}$ & $\mathrm{I} / 2$ & 5 & 2 \\
\hline 3 & $x$ & $x$ & $x$ & $N$ & I & 20 & 2 \\
\hline 3 & $x$ & $x$ & $x$ & $\mathrm{~N}$ & 2 & 3 & 2 \\
\hline & & & & & & & 3 \\
\hline
\end{tabular}


Table 3 (Continued)

\begin{tabular}{|c|c|c|c|c|c|}
\hline Gender & Age & $\begin{array}{l}\text { Primary diagnosis } \\
\text { (pain indication/ cause of pain) }\end{array}$ & Localization of pain symptoms & $\begin{array}{l}\text { Duration of } \\
\text { pain in years }\end{array}$ & Hyperalgesia \\
\hline M & 36 & Scar pain after inguinal hernia repair & Inguinal hernia region & 0.33 & $\mathrm{x}$ \\
\hline $\mathrm{F}$ & 55 & $\begin{array}{l}\text { Postoperative pain after } \\
\text { popliteal artery stenting }\end{array}$ & Anterior aspect of the skin & 2.0 & \\
\hline $\mathrm{F}$ & 68 & Left TKR postsurgical knee pain ${ }^{e}$ & Left anterior knee & 3.0 & $x$ \\
\hline M & 31 & $\begin{array}{l}\text { Neuropathy after inguinal hernia } \\
\text { operation }\end{array}$ & Left and right inguinal region & 6.0 & $x$ \\
\hline $\mathrm{F}$ & 32 & Post-traumatic pain in the right wrist & $\begin{array}{l}\text { In the lateral external port } \\
\text { of the right wrist }\end{array}$ & 1.5 & $\mathrm{X}$ \\
\hline $\mathrm{F}$ & 69 & $\begin{array}{l}\text { Neuropathic pain over right } \\
\text { knee failing TKR }\end{array}$ & Periarticular, right knee & 0.5 & \\
\hline $\mathrm{F}$ & 36 & $\begin{array}{l}\text { Pain inguinal after operation } \\
\text { of hernia }\end{array}$ & Left inguinal region & 0.25 & \\
\hline $\mathrm{F}$ & 72 & Trigeminal pain after ear operation & VI & 2.0 & $x$ \\
\hline M & 65 & Postherniorrhaphy inguinal right & Area of the surgery (right inguinal) & 1.0 & $x$ \\
\hline M & 52 & $\begin{array}{l}\text { Postoperative foot pain (inguinal } \\
\text { hernia repair) }\end{array}$ & Internal side of right big toe & 0.15 & \\
\hline M & 44 & $\begin{array}{l}\text { Complex regional pain syndrome II - } \\
\text { postamputation }\end{array}$ & Stump of the right thumb & 5.0 & \\
\hline M & 40 & Right inguinal hernia repair & Scar and inguinal area & 2.0 & \\
\hline
\end{tabular}

with both etiologies present (Table 2) were included in the calculations of baseline data.

The majority of patients ( $83 \%$ ) received lidocaine plaster as add-on therapy. Seventy-six percent of all patients showed much or very much improvement (as rated on the CGIC) during treatment with 5\% lidocaine medicated plaster. The 10 patients (17\%) receiving monotherapy were all very much or much improved.

Similar to the nLBP cases, the presence of hyperalgesia was clearly associated with a better treatment outcome and considered to have some predictive value. Of the patients showing much or very much improvement on the CGIC, 75\% had initially experienced hyperalgesia compared with $46 \%$ of patients with minimal or no improvement. The presence of allodynia was documented for the vast majority (81\%) of patients; $66 \%$ of much or very much improved patients had initially presented with "painful" or "extremely painful" allodynia compared with $54 \%$ of patients with minimal or no improvement. From the submitted case reports, no clear association between the occurrence of allodynia, duration of pain, or pain quality (burning, shooting, stabbing, or other), and treatment response was apparent. There was also no obvious impact of diagnosis or site of pain on treatment outcome. Nevertheless, based on general treatment experience shared in the discussion groups, patients with allodynia, hyperalgesia, and spontaneous pain like burning or shooting were felt to be good candidates for treatment with lidocaine plaster. Long-lasting pain was thought to be associated with a negative treatment outcome by some of the physicians. Localized pain as opposed to widespread or generalized pain and positive sensory symptoms, like dysesthesias, were clearly identified as predictors for treatment with lidocaine plaster, whereas spontaneous pain without evoked pain and negative sensory symptoms, such as anesthesias or hypoesthesias, were considered linked with negative treatment outcomes. No predictive value was associated with paresthesia.

Superficial spontaneous (nonevoked) pain was considered to be a positive predictor as opposed to deep or widespread pain for treatment with lidocaine plaster. A 19-year-old male with spinal dystonia who received an abdominal neuromodulator implant developed superficial scar pain after surgery, including tactile allodynia (rated 7-10 on a VAS scale). Lidocaine plaster treatment resulted in satisfactory pain relief. A 51-year-old female with bipolar disorder who received a neuromodulator implant in the thorax experienced deep pain after surgery, perhaps generated by deeper nerve trauma and an inflammatory seroma. In contrast with the first case, she did not benefit from lidocaine plaster. 
Table 3 (Continued)

\begin{tabular}{|c|c|c|c|c|c|c|c|}
\hline $\begin{array}{l}\text { Allodynia/allodynia } \\
\text { severity rating }\end{array}$ & $\begin{array}{l}\text { Stabbing } \\
\text { pain }\end{array}$ & $\begin{array}{l}\text { Burning } \\
\text { pain }\end{array}$ & $\begin{array}{l}\text { Shooting } \\
\text { pain }\end{array}$ & Monotherapy & $\begin{array}{l}\text { Plasters } \\
\text { per day }\end{array}$ & $\begin{array}{l}\text { Duration of plaster } \\
\text { treatment (months) }\end{array}$ & CGIC score \\
\hline 0 & & & & $\mathrm{~N}$ & $\begin{array}{l}\text { I/8 } \\
\text { twice a week }\end{array}$ & 2 & 2 \\
\hline 2 & & $x$ & & $\mathrm{~N}$ & $\mathrm{I} / 2$ & $\begin{array}{l}10 \\
\text { ongoing }\end{array}$ & 2 \\
\hline$x$ & & $x$ & & $\mathrm{~N}$ & 2 & I & 3 \\
\hline 2 & & & $X$ & $\mathrm{~N}$ & $1 / 2$ & 1 & 3 \\
\hline 3 & & $x$ & & $\mathrm{~N}$ & 1 & 12 & 3 \\
\hline 2 & $x$ & $x$ & $x$ & $\mathrm{~N}$ & 1 & NA & 3 \\
\hline 0 & & $x$ & $X$ & $\mathrm{~N}$ & I & $\begin{array}{l}8 \\
\text { ongoing }\end{array}$ & 3 \\
\hline 0 & & & & $\mathrm{~N}$ & $\mathrm{I} / 2$ & 3 & 3 \\
\hline 2 & & $x$ & & $\mathrm{~N}$ & 1 & 1 & 3 \\
\hline 2 & & & $x$ & $\mathrm{~N}$ & $1 / 8$ & 1 & 3 \\
\hline 3 & & & $\mathrm{x}$ & $\mathrm{N}$ & $1 / 8$ & I & 4 \\
\hline 1 & $x$ & $x$ & & $\mathrm{~N}$ & $1 / 2$ & I & 4 \\
\hline
\end{tabular}

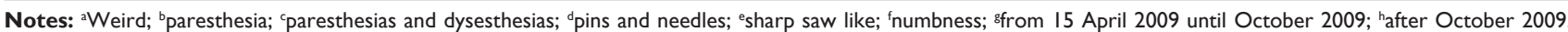
Allodynia severity rating: 0 = no pain or discomfort to touch, I = uncomfortable, but tolerable to touch, 2 = painful, 3 = extremely painful, patient cannot stand touching; duration of pain was converted to years, term "many years" was set to $\geq 5$ years in the table and to 5 years for calculation of means.

Abbreviations: CGIC, Clinical Global Impression of Change ( 1 = very much improved, $2=$ much improved, $3=$ minimally improved, $4=$ no change, $5=$ minimally worse, 6 = very much worse); F, female; M, male; NA, not available; NR, not readable; TKR, total knee replacement; X, symptom present.

\section{Chronic neuropathic back pain after surgical trauma}

Seventeen case reports with a diagnosis of both PNCCP and nLBP were submitted and discussed in the nLBP and the PNCCP groups $(41.2 \%$ male, mean age $50.6 \pm 16.0$ years (Table 2). Although the mean duration of pain was $2.9 \pm 4.2$ years, one patient had an exceptionally long duration of pain of 18 years, giving a mean pain duration in the group of $1.9 \pm 1.7$ years without inclusion of this outlier.

All except for one patient received lidocaine plaster as an add-on to pre-existing pain medication, and $76 \%$ of the patients showed much or very much improvement (as rated on the CGIC) during treatment with $5 \%$ lidocaine medicated plaster. The one patient receiving monotherapy was very much improved.

The majority of patients presented with hyperalgesia $(76 \%)$ and allodynia (64\%). Burning, shooting, or stabbing pain were experienced by $71 \%, 47 \%$, and $35 \%$, respectively. The patient with an exceptionally long duration of pain (18 years) was a particularly interesting case. This 69-year-old male underwent two surgical procedures in the early 1990s (transurethral resection of prostate and drainage of a spinal epidural empyema in the context of Conn syndrome (bladder and bowel dysfunction, failed back surgery syndrome).
His average pain score on the NRS prior to initiation of lidocaine plaster treatment was $8-9$, with a maximum of 10 , and he presented with hyperalgesia, painful to extremely painful allodynia, lumbar pain around the incision scar, and shooting pain triggered by pressure, anesthesia at S4-S5, hypoesthesia at $\mathrm{S} 3$, and pelvic paresthesia. His pre-existing regimen of trimetazidine, furadantine, lansoprazole, chlordiazepoxideclidinium bromide, and naproxen as required was stopped, and treatment with capsaicin, pregabalin, amitriptyline, tramadol, and lidocaine plaster was initiated. One month after the start of this regimen, pregabalin, amitriptyline, and tramadol were stopped due to the occurrence of adverse events, and pain has since been successfully controlled (very much improved) by capsaicin and lidocaine plaster.

Eighteen adverse events in 11 patients were reported on the 89 case report forms submitted. Mild application site reactions were the most common (six patients) and were considered likely related to lidocaine plaster treatment in five patients. Further adverse events were nausea $(n=2)$, vomiting $(\mathrm{n}=1)$, somnolence $(\mathrm{n}=1)$, and dizziness $(\mathrm{n}=1)$. One patient had moderate diarrhea and severe vertigo, and one presented with severe depression, anxiety, suicide ideation, and worsening of pain. Except for an unclear relationship for "dizziness" and no available assessment for the patient with somnolence 
and nausea, none of the other adverse events were considered to be related to lidocaine plaster treatment. Three patients discontinued owing to adverse events (two application site reactions, one episode of dizziness).

\section{Summary}

Discussions in the four groups achieved similar conclusions regarding positive and negative outcome predictors for the treatment of nLBP and PNCCP with 5\% lidocaine medicated plaster (Table 4).

There was general agreement that hyperalgesia and/or allodynia and localized pain, as opposed to widespread or generalized pain, are predictive of treatment success in both indications. Pain quality (ie, burning, stabbing, shooting) was judged to be a positive predictor for PNCCP and nLBP after surgical trauma, but the physicians felt it was not reliable enough for the prediction of treatment outcome for nLBP. Besides hyperalgesia and allodynia, other positive sensory phenomena, such as dysesthesia, were linked to treatment success, whereas negative sensory phenomena, such as anesthesia and hypoesthesia, were assessed to be associated with poorer outcomes. Paresthesia and diagnosis/site of pain were considered to be of no predictive value.

The case reports discussed at the meeting were contributed at the discretion of each physician, which introduces a possible selection bias, in that they are not necessarily representative of the entire treated population, but may allow a first assessment of the drug's effectiveness in various neuropathic low back pain and post-traumatic pain conditions.

In all discussion groups, the clinical experience of participants clearly pointed to allodynia as a major positive predictor of treatment success with the plaster for the two indications. Previous case reports showing improvement of allodynia in patients with chronic low back pain ${ }^{15}$ and $\mathrm{PNCCP}^{11,12}$ using lidocaine plaster as an adjunct to existing pain therapy support the findings. The identification of allodynia as one potential predictor for treatment success in $\mathrm{nLBP}$ and PNCCP is consistent with treatment experience in other indications. Several randomized controlled trials have shown clinically relevant effects on the reduction of allodynia in patients with postherpetic neuralgia and other focal peripheral neuropathic pain conditions, ${ }^{3,5,26,27}$ which mirrors the clinical experience of participants at the previous two meetings in Athens (2007) and Berlin (2008). They considered allodynia and hyperalgesia as positive predictors for treatment success in postherpetic neuralgia, diabetic polyneuropathy, trigeminal neuralgia, and complex regional pain syndrome. Because different neuropathic pain conditions share common symptoms, the experts summarized their overall experience with 5\% lidocaine medicated plaster during their final discussion and ranked potential predictors on the basis of published evidence and their own experience in different indications as proposing relatively high, medium, or low treatment success (Table 5).

This led to the hypothesis that the value of predictors combined with an indication might indicate the likelihood of success. Furthermore, it was generally agreed by the participating clinicians that this symptom-based approach is preferable to an indication-based approach when selecting pain medication. The view that the classical indication/disease-based treatment approach might have to be reconsidered is echoed in recent publications ${ }^{28,29}$ and a lot

Table 4 Potential predictors for treatment success with $5 \%$ lidocaine medicated plaster

\begin{tabular}{lll}
\hline Predictive value & $\begin{array}{l}\text { Chronic low back pain } \\
\text { with neuropathic components }\end{array}$ & $\begin{array}{l}\text { Chronic neuropathic pain after } \\
\text { surgical and nonsurgical trauma }\end{array}$ \\
\hline Positive & Localized pain & Localized pain \\
& Hyperalgesia & Hyperalgesia \\
& Allodynia & Allodynia \\
& Differentiation between back & Superficial pain \\
& pain and nonback pain & Pain quality \\
& Long duration of pain & Positive sensory symptoms (eg, dysesthesia) \\
Negative & Predominant radicular pain & Long duration of pain \\
& Widespread pain & Spontaneous pain without evoked pain \\
& & Deep pain \\
& & Widespread pain \\
Uncertain & & Negative sensory symptoms \\
No value & (eg, anesthesia, hypoesthesia) \\
& Pain quality & Diagnosis of pain
\end{tabular}

Notes: Pain quality = burning, shooting, stabbing, or other descriptors of pain. ${ }^{\text {aPain }}$ of long duration is difficult to treat with any pain medication. 
Table 5 Probability of treatment success with $5 \%$ lidocaine medicated plaster

\begin{tabular}{lll}
\hline Probability & Potential predictors & Indication \\
\hline High & Localized pain & Postherpetic neuralgia \\
& Superficial pain & Diabetic polyneuropathy \\
& Allodynia & Trigeminal neuralgia \\
& & Chronic postsurgical pain \\
& & Complex regional pain \\
& & syndrome \\
Medium & Hyperalgesia & Low back pain (chronic) \\
& Burning & Carpal tunnel syndrome \\
& Stabbing & Cancer pain \\
& Shooting & \\
& Numeric rating scale score & \\
Low & Deep pain & Central pain \\
& Numbness & Fibromyalgia \\
& Radiating pain & Arthrosis \\
& Radicular pain & Gout \\
& Heavy sweating & Phantom limb pain \\
& Pain site distant from nerve & Muscular pain \\
& damage & \\
Chronic widespread & \\
\hline
\end{tabular}

of effort have been made to classify patients on the basis of their somatosensory profile, with the ultimate goal of finding new treatment approaches for chronic neuropathic pain, focusing on symptoms, signs, and pathophysiologic mechanisms rather than on underlying disease alone. ${ }^{30,31} \mathrm{In}$ addition, there is an urgent need to accumulate clinical data which, in turn, could help to determine therapeutic outcomes and criteria that a novel analgesic drug should meet in order to be a clinically worthwhile drug.

Some further general observations for treatment success with lidocaine plaster included a crucial requirement for clinical examination with a possible diagnosis of neuropathic pain. However, it was generally agreed by the participants from the nLBP groups that a clear definition for neuropathic back pain is lacking. Furthermore, early treatment is recommended, in particular with regard to neuropathic PNCCP. According to the experience of the participants, healing after surgery can take up to six months, so it was suggested that lidocaine plaster treatment should be initiated 1-2 weeks following surgery in order to prevent pain from becoming chronic. Patients with a long duration of pain are difficult to treat with any analgesic, and the lidocaine plaster is likely to be used as add-on therapy because it would be impossible to stop existing systemic treatment in most cases (although decreased dosing of these concomitant medications is often possible). However, an analysis of the case report data concerning a potential relationship between pain duration and treatment outcome did not show a trend towards a more favorable treatment effect in patients with a short duration of pain. Motivation and realistic expectations of the patients were also regarded as a prerequisite to treatment success. Furthermore, many participants commented that patients with psychologic problems are generally difficult to treat with any analgesic.

In summary, the findings of this conference have identified several predictors for treatment success with 5\% lidocaine medicated plaster in the indications of chronic nLBP and neuropathic PNCCP. Common symptomatology with other neurologic indications suggests that treatment of localized neuropathic pain symptoms with the plaster can be considered across different neuropathic pain indications.

\section{Acknowledgments}

The authors wish to thank all participating pain specialists for their contributions. The participating pain specialists were B Gustorff, C Lampl, R Likar, S Quasthoff(Austria), M Dangoisse, S Goossens, G Hans, P Vanelderen, H Verschueren (Belgium), J Espinoza (Colombia), S Grazio (Croatia), D Ammar, L Brasseur, J Nizard, M-T Gatt, B Planchet Barraud, M Sorel (France), B Kukowski, A Potschka, G Reifschneider, S Ries, M Schenk (Germany), L De Martini, M Evangelista (Italy), AJM van Wijck (The Netherlands), M Kocot-Kępska, A Przeklasa-Muszyńska (Poland), D Fernandes, L Lemos, MP Ribeiro da Silva (Portugal), AG Raphailovna (Russia), N Krcevski Skvarc (Slovenia), E Catalá, L San Norberto (Spain), J Bogefeldt, D Kadetoff (Sweden), M Bone, G Browne, S Khot, A Nicolaou, M Platt (UK), B Nicholson, S Nalamachu (US), G Bencosme (Venezuela) Further thanks go to Elke Grosselindemann (Brett Medical Writing, Australia) and Birgit Brett (Brett Medical Writing, Germany) for editorial assistance and publication coordination.

\section{Disclosure}

This meeting was facilitated by Grünenthal $\mathrm{GmbH}$, Aachen, Germany. Costs associated with this publication were met by Grünenthal. AN has received consultancy and speaker honoraria from Grünenthal in the past 12 months. BN has received consultancy fees from Grünenthal and Endo in the past 12 months. GH has received research funding and consultancy honoraria from Grünenthal in the past 12 months. LB received compensation for moderating the Vienna meeting.

\section{References}

1. Dworkin RH, O'Connor AB, Audette J, et al. Recommendations for the pharmacological management of neuropathic pain: An overview and literature update. Mayo Clin Proc. 2010;85 Suppl 3:S3-S14.

2. Argoff CE. New analgesics for neuropathic pain: The lidocaine patch Clin J Pain. 2000;16:S62-S66. 
3. Baron R, Mayoral V, Leijon G, et al. 5\% lidocaine medicated plaster versus pregabalin in post-herpetic neuralgia and diabetic polyneuropathy: An open-label, non-inferiority two-stage RCT study. Curr Med Res Opin. 2009;25:1663-1676.

4. Baron R, Mayoral V, Leijon G, et al. Efficacy and safety of combination therapy with $5 \%$ lidocaine medicated plaster and pregabalin in postherpetic neuralgia and diabetic polyneuropathy. Curr Med Res Opin. 2009;25:1677-1687.

5. Binder A, Bruxelle J, Rogers P, et al. Topical 5\% lidocaine (lignocaine) medicated plaster treatment for post-herpetic neuralgia: Results of a double-blind, placebo-controlled, multinational efficacy and safety trial. Clin Drug Investig. 2009;29:393-408.

6. Hans G, Sabatowski R, Binder A, et al. Efficacy and tolerability of a 5\% lidocaine medicated plaster for the topical treatment of post-herpetic neuralgia: Results of a long-term study. Curr Med Res Opin. 2009;25: 1295-1305.

7. Rowbotham MC, Davies PS, Verkempinck C, Galer BS. Lidocaine patch: Double-blind controlled study of a new treatment method for post-herpetic neuralgia. Pain. 1996;65:39-44.

8. Barbano RL, Herrmann DN, Hart-Gouleau S, et al. Effectiveness, tolerability, and impact on quality of life of the $5 \%$ lidocaine patch in diabetic polyneuropathy. Arch Neurol. 2004;61:914-918.

9. Herrmann DN, Barbano RL, Hart-Gouleau S, et al. An open-label study of the lidocaine patch $5 \%$ in painful idiopathic sensory polyneuropathy. Pain Med. 2005;6:379-384.

10. Nalamachu S, Crockett RS, Gammaitoni AR, Gould EM. A comparison of the lidocaine patch 5\% vs naproxen $500 \mathrm{mg}$ twice daily for the relief of pain associated with carpal tunnel syndrome: A 6-week, randomized, parallel-group study. MedGenMed. 2006;8:33.

11. Hans G, Joukes E, Verhulst J, Vercauteren M. Management of neuropathic pain after surgical and non-surgical trauma with lidocaine 5\% patches: Study of 40 consecutive cases. Curr Med Res Opin. 2009;25: 2737-2743.

12. Brabant S, Nagels W. Topical lidocaine 5\% patch for the treatment of chronic postsurgical neuropathic skin pain. Pain Pract. 2009;9(S1):35.

13. Galer BS, Gammaitoni AR, Oleka N, et al. Use of the lidocaine patch $5 \%$ in reducing intensity of various pain qualities reported by patients with low-back pain. Curr Med Res Opin. 2004;20 Suppl 2:S5-S12.

14. Gimbel J, Linn R, Hale M, Nicholson B. Lidocaine patch treatment in patients with low back pain: Results of an open-label, nonrandomized pilot study. Am J Ther. 2005;12:311-319.

15. Hines R, Keaney D, Moskowitz MH, Prakken S. Use of lidocaine patch $5 \%$ for chronic low back pain: A report of four cases. Pain Med. 2002; 3:361-365.
16. Braun J, Inman R. Clinical significance of inflammatory back pain for diagnosis and screening of patients with axial spondyloarthritis. Ann Rheum Dis. 2010;69:1264-1268.

17. Argoff CA, Wheeler AH. Spinal and radicular pain disorders. Neurol Clin. 1998;16:833-850.

18. Wheeler AH, Murrey DB. Spinal pain: Pathogenesis, evolutionary mechanisms, and management. In: Pappagallo M, editor. The Neurological Basis of Pain. McGraw-Hill; 2005.

19. Kirkaldy-Willis WH, Wedge JH, Yong-Hing K, Reilly J. Pathology and pathogenesis of lumbar spondylosis and stenosis. Spine (Phila Pa 1976).1978;3:319-328.

20. Selby DK. The structural degenerative cascade: The lumbar spine. In: White AH, Schofferman JA, editors. Spine Care: Diagnosis and Conservative Treatment. St Louis, MO: Mosby; 1995.

21. Freynhagen R, Baron R. The evaluation of neuropathic components in low back pain. Curr Pain Headache Rep. 2009;13:185-190.

22. Bogduk N. On the definitions and physiology of back pain, referred pain, and radicular pain. Pain. 2009;147:17-19.

23. Macrae WA. Chronic post-surgical pain: 10 years on. Br J Anaesth. 2008;101:77-86.

24. Mahn F, Baron R. Types of topical treatment for peripheral neuropathic pain. Mechanism of action and indications. Schmerz. 2010;24:317-325. German.

25. O'Connor AB, Dworkin RH. Treatment of neuropathic pain: An overview of recent guidelines. Am J Med. 2009;122(10 Suppl):S22-S32.

26. Meier T, Wasner G, Faust M, et al. Efficacy of lidocaine patch $5 \%$ in the treatment of focal peripheral neuropathic pain syndromes: A randomized, double-blind, placebo-controlled study. Pain. 2003;106:151-158.

27. Wasner G, Kleinert A, Binder A, et al. Postherpetic neuralgia: Topical lidocaine is effective in nociceptor-deprived skin. J Neurol. 2005;252:677-686.

28. Jensen TS, Baron R. Translation of symptoms and signs into mechanisms in neuropathic pain. Pain. 2003;102:1-8.

29. Maier C, Baron R, Tölle TR, et al. Quantitative sensory testing in the German Research Network on Neuropathic Pain (DFNS): Somatosensory abnormalities in 1236 patients with different neuropathic pain syndromes. Pain. 2010;150:439-450.

30. Rolke R, Baron R, Maier C, et al. Quantitative sensory testing in the German Research Network on Neuropathic Pain (DFNS): Standardized protocol and reference values. Pain. 2006;123:231-243.

31. Baron R, Binder A, Wasner G. Neuropathic pain: Diagnosis, pathophysiological mechanisms, and treatment. Lancet Neurol. 2010;9:807-819.
Journal of Pain Research

\section{Publish your work in this journal}

The Journal of Pain Research is an international, peer-reviewed, open access, online journal that welcomes laboratory and clinical findings in the fields of pain research and the prevention and management of pain. Original research, reviews, symposium reports, hypothesis formation and commentaries are all considered for publication.

\section{Dovepress}

The manuscript management system is completely online and includes a very quick and fair peer-review system, which is all easy to use. Visit http://www.dovepress.com/testimonials.php to read real quotes from published authors. 